\title{
I Am Roha's Emaye: A Critical Autoethnography of Mothering in Liminal Spaces
}

\author{
Kara Roop Miheretu *(D) and Allison Sterling Henward $(\mathbb{C}$ \\ Department of Curriculum and Instruction, Penn State University, State College, PA 16801, USA; ash55@psu.edu \\ * Correspondence: khr35@psu.edu
}

Received: 30 October 2019; Accepted: 31 December 2019; Published: 31 March 2020

\begin{abstract}
In this critical autoethnographic study, we examine how one woman, Roha's emaye (Amharic for mother), developed necessary racialized subjectivities as mother of a child who codes as Black in contemporary U.S. society. While substantial research outlines how mothers of color must prepare children to live in a racist world; typically, this perspective focuses on the child. Often, it excludes how mothers-both Black and White-must 'do' identity work to make sense of this. Although race is a social and cultural construct, when women cross the color line to partner and have children, the challenges they face both as part of a couple and mother are real. Data are drawn from journals and memories, blending self-observation and reflexive investigation as fieldwork to intentionally comment on and critique cultural practices surrounding mothering and subjectivity. Data were analyzed using Foucauldian concepts of Genealogy, Power, and Subjectification. Findings indicate that this mother was constructed, regulated, normalized, and categorized and found to occupy multiple liminal spaces. This paper argues that tracing how particular subjectivities are given power and regulated in specific contexts of mothering contributes nuanced understandings of how race comes to matter, for whom, and when.
\end{abstract}

Keywords: mothering; subjectivity; race; multiracial families; Foucault

When Roha was two, my mother warned me, "Roha needs a haircut, so he doesn't look like he is Black." Stunned and puzzled, I replied, "What does that mean?" My mother shrugged, "You know what it means."

\section{Introduction to Mothering}

Roha arrived on 14 September 2014, in New York, born to my husband, who is Ethiopian and me, a White U.S. woman. Sitting in the sterile hospital room hours after his birth, I held him tight and pulled a tiny woven hat over his dark curly hair. His warm cocoa skin provided a stark contrast to the pastel blanket wrapping his small precious body. For me, the thin sheets provided no barrier to the freezing air, but I was tired. Settling into my bed, I turned on the news. Footage of a large, tall Black man being wrestled to the ground by two police officers flashed across the screen. I watched in horror as this man cried, 'I can't breathe' eleven times, only to be suffocated. Eric Gardner, the newscaster then reported, was the second man (joining Michael Brown) who was killed by police. I froze. As I looked from this horror to my Roha, whose skin looked far closer to those men on the television than to my own, I too suddenly couldn't breathe.

As a critical scholar of early childhood, I had long been interested in the ways race affects educational policy, classroom practice, and the everyday lives of children. I was aware that Black children have been the target of specific school-wide policies that police their bodies (Dumas 2016); Black children are routinely suspended, expelled and subjected to more punitive punishments in schools, and a higher disproportion of Black boys are labeled as having a disability and placed in special education classes (Love 2014, 2016). In and out of schools, Black boys need to have a more 
heightened sense of where they are and learn to display compliance to authority figures to counteract socially constructed stereotypes and fear of Black males (Love 2014).

Now, as a White mother to a Black son, it would become my every day. A White mother who was, as a function of racial privilege, always given the choice of stepping into this world-choosing when and if to engage with issues of race, supremacy, and justice (Pollock 2009). Beginning in September 2014, I had to reconsider all to become the mother my Black son needed.

This is a critical autoethnographic study of mothering in liminal spaces (Rollock 2012) as Roha's emaye (Amharic for mother). Racialized Others' have been shown to occupy a liminal space of alterity, a position at the edges of society from which their identities and experiences are constructed (Rollock 2012, p. 65). Here we explore what it means to develop necessary racialized subjectivities as a mother of a child who codes as Black in contemporary U.S. society. While substantial research outlines how mothers of color must prepare children to live in a racist world, typically, this perspective focuses on the child. Often, scholarship overlooks how mothers-both Black and White (Rauktis et al. 2016; Kouritzin 2016) must "do" identity work to make sense of this. Although race is a social and cultural construct, when women cross the color line to partner and have children, the challenges they face both as part of a couple and mother are real (Roots 2001).

A note on terminology:

In this manuscript, we use "African American" as it relates to identity and culture. We use Black to describe the way African-American and Afro-Caribbean people are constructed in light of race and racism in the U.S. Additionally, here we use "I" to capture Kara's experiences and "we" in analysis to account for authorship.

\section{Autoethnographic Lenses to Motherhood}

In this study, we draw upon journals and memories to examine how Kara began to mother in liminal spaces. Informed by the work of Ellis et al. (2011), this autoethnographic endeavor blends self-observation and reflexive investigation as the fieldwork to intentionally comment on and critique cultural practices surrounding mothering and subjectivity (p. 22). Autoethnography is a way of producing meaningful, accessible, and evocative research grounded in personal experience, research that sensitizes readers to issues of identity politics, experience shrouded in silence to deepen our capacity to empathize with people (Ellis and Bochner 2000).

In using autoethnography as a method, we privilege the narrative of often untold stories, noting that narratives are pivotal in feminist theories and scholarship (Goodall 2008). Using autoethnography allows us to think about Kara's experiences raising Roha and how they might relate to the broader cultural politics of motherhood. Our focus in this is how racial subjectivity comes to matter in how we experience the world. As Thompson and Tyagi (1996) in (Gatson 2003, p. 21) note "race is about everything-historical, political, personal-and race is about nothing-a construct, an invention that has changed dramatically over time and historical circumstance. Race has been and continues to be, encoded in all of our lives" (p. ix). That encoding process is a sociological one. Here, we share relational and institutional stories of mothering, noting how these stories are always and continually impacted by history and social structure (Ellis 1999). In reflecting on these experiences, we recognize this "not as a veridical act that reproduces the original lived experience, but instead one constituted from a particular time and place and discursive frame" (Gannon 2006, p. 483). We acknowledge and accommodate (multiple) subjectivities, emotionality, and their influence on the research, "rather than hiding from these matters or assuming they don't exist" (Ellis et al. 2011, p. 274). In an attempt to contribute to research on mothering, we embrace the haunting vulnerability of these stories, aiming to connect experiences to those of readers (p. 22).

In scholarly and popular discourses, Kara raising Roha is described as "interracial parenting," "mixed-race parenting," "multiracial parenting" (Donnella 2016; Murad 2005). But the language used to categorize and record personal backgrounds intertwines into ideological and political debates (Caballero 2005). For Kara, it feels more like Black + White $(B+W)$. Given the sharp increase in 
the number of children claiming multiracial lineage in the U.S., more mothers are creating new paths of experiences (Jones and Bullock 2013). To date, little work has addressed how mothers who differ in race from their children might engage in work of racialized mothering. As outlined below, we aim to contribute to social change and action by addressing the ways that discourses work to limit conceptualizations and practices of mothering in multiracial families (Ellis and Bochner 2000).

\section{Motherhood, Subjectivity, and Genealogy}

We turn to poststructural traditions, which reject fixed, monolithic, and modernist constructs of identity. Since the discursive turn, researchers have sought to understand how language and power assemble, order, and construct (among other things) reality, power, and identity, and in turn, how subjectivities produce and are produced (Grace and Henward 2013). Poststructural notions of identity typically recognize motherhood as a social construction, informed by multiple, overlapping discourses that are culturally recognizable, socially acceptable and always ratified by social actors in different contexts (Scott and Henward 2016). Subjectivities are affective and always produced with others (Zembylas 2003) - mothers pick up, assemble and construct subjectivities at the intersection of many competing discourses and practices, all of which position and designate the subject (Walkerdine 2003). Discourses are understood to "form the objects of which they speak" (Foucault 1972, p. 49). We find this approach helpful in accounting for how Kara is always considered in relation to Roha, how subjectivities are informed by discourses of motherhood, and how this is picked up when Kara is with Roha. While we consider both Kara and Roha, our analytic concern is with how Kara's subjectivity is constituted.

We consider autoethnography a poststructural method (Gannon 2006). While some autoethnographers argue for an onto-epistemological paradox between traditional autoethnographic accounts (that presume fixed, unitary subjects who can speak for themselves) and poststructural lenses (that stress the (im)possibilities of ever fully writing the self), we do not view this as an incommensurable tension (Gannon 2006). Textual strategies that evoke fractured, fragmented subjectivities and provoke discontinuity, displacement, and estrangement offer the possibility to understand how contingent, multiple, and situational subjectivities can and do operate in relation to historical and contemporary discourses of oppression. As we show, theoretical models concerned with power and language and which emphasize "ruptures, tensions, inconsistencies, and instability" (Henward 2018, p. 226) allow for new understandings of how race comes to matter, for whom, and when in mothering.

In this pursuit, Arribas-Ayllon and Walkerdine (2008) three concepts of discourse analysis (Genealogy, Power, and Subjectification) are helpful in understanding how $\mathrm{B}+\mathrm{W}$ are produced in context. Genealogy is a deconstructive method used to trace discourses and "truths". It focused on their origin and historical conditions but also the ways in which they are given power in and across time and in space. Power refers to the tracing of mechanisms and discourses that produce power but also the role of power in sustaining certain discourses. Of central concern is how power produces and reproduces what is accepted, normalized, and therefore taken for granted in a given society (Gore 1995). Arribas-Ayllon and Walkerdine (2008) final concept, subjectification, investigates how discourses operate to produce subjects based on their material/signifying practices (p. 91). Each concept matters in how mothers are understood, regulated, and ultimately constituted. Foucauldian theory understands networks of power as far from contained, as something existing in interchanges between individuals. Consequently, $\mathrm{B}+\mathrm{W}$ subjectivity is not something produced between Roha and Kara but constituted by various discourses and interactions and receptions in our many social, cultural, and political contexts.

\section{Roha's Arrival and My Becoming Liminal}

It is 2014, and I am living in New York City. I am pregnant and beginning to engage with the world as a mother. Walking in and among one of the most ethnically, racially, culturally, and linguistically diverse cities in the country, I notice mothering, because I have realized, I am joining their ranks. And I am struck by the Whiteness of it all-Mothering is White. White mothers smiling and cooing 
at pale babies on bottle advertisements, in brochures in the obstetrician's office, and on baby stroller boxes. The match of skin tone is so exact it is sometimes difficult to see where the mother's skin ends and the baby's begins. Occasionally I see a child and mother of color, an exception in this sea of Whiteness. They too look alike. I am continually reminded that while my skin matches the pale peach hue of mothers on the glossy paper, my baby's skin will likely resemble the mahogany complexion of my husband. "We" cannot be found in mom-to-be books, and I understood at this moment that my motherhood might always code as an exception. I felt incensed, but I pushed it to the back of my mind because, after all, a baby was on the way.

Our subjectivity is wrapped up into our skin color (Mama 2002). At this moment, my subjectivity felt only that of 'not.' I am confused, unsettled, and unable to locate myself. Foucault notes that all knowledge is produced, normalized, and sustained in everyday encounters. Historical conditions produce discourses, shaping how these appear in the present. The normalized mother and baby were White + White-I/we are not. As media scholar Seiter (1990) notes, "there is nothing innocent about the use of children in advertising. Each infant crawling across the screen carries a heavy load of ideological projections" (p. 31). This can be understood as normalization of racialized discourses of parenting (Gore 1995). I began to experience my first glimpse of mothering, where "experiences of becoming and being mothers are inextricably linked to race, social class, age, and social, cultural location and as a result are diverse and fragmented" (Miller 2005, p. 46) While not clear at the time, it was an example of how "dominant forms of knowledge and associated practices shape the context in which mothering occurs" (Miller 2005, p. 46).

The day my Ethio-American son was born was the day that I gained the subjectivity of mother that would confront discourses of race, otherness, belonging, and exception. After his joyous arrival, I slowly learned from those around me what it meant to be a mother to a Black child. My identity and expectations were framed by those around me, by what people thought I should be, should do. And these were wrapped in my skin, his skin, our B + W.

\section{The Racialized 'Others' in the Cornfield}

Late in the year, shortly after Roha's birth, I left New York City for a visit with my family. In New York, I had settled into motherhood, sometimes but not always thinking about my/our racial position. I was more concerned with quotidian experiences of mothering. Race came and went from my mind in the moments of bathing, feeding, and sleepless nights. However, visiting my rural, White, conservative farming family in the Northeastern United States, where my mothers' side is proud of their Appalachian heritage, and my fathers' is devotedly religious, Brethren, I was sharply reminded and put on guard. This town, while a place of strength, is also a context in which Whiteness is normalized and celebrated. In my small hometown, that is surrounded by farms for miles, it is not uncommon to see the confederate flag flying outside a house or affixed to a truck, which in some cases might accompany a full gun rack in the back window. As we entered the town, I felt myself aware of us; I am, and we are, B + W.

Late one afternoon, we sat on my parent's patio overlooking a sea of corn, soybeans, and alfalfa-fields my family worked for generations. Roha sat on my lap. At the time he had developed eczema, which meant there are places on his body that were red, bare, and which relentlessly irritated him. As his hands searched to provide relief, he would scratch so hard he sometimes drew blood. His creamy skin color, more like my husband's highlighted the angry red eczema patches all over his body. I covered his beautiful dark skin with an emollient cream at the request of his doctor. As a busy baby, he often wiped off the cream as he explored his world. As a busy mother, I was forever replacing it. As my family reconnected, a distant family member pointed and queried about his skin condition. Eczema, I explained. She countered in a way that shook me to my core, "he has eczema because his skin is used to the African sun, so ... maybe he could go back there?" As I would come to learn, this was but the first of far more scathing, racist comments and my first foray into what it meant for us to be $\mathrm{B}+\mathrm{W}$ in this family. 
Roha was born with a few health issues, most notably a condition that reversed his organ positions. As parents it was scary, but our manageable reality. For my relatives, his health concerns revealed more deep-seated tensions of what it meant to be $\mathrm{B}+\mathrm{W}$ in my hometown. In speaking with a relative a few months later, I learned that his health was proof of the "unnaturalness" of my marriage. While her exact venomous words escape me to this day, Roha's health was "a punishment" for me not "obeying God's law", which for her, dictated I marry and have children with a White man. Outwardly, I cringed at these comments. Inwardly, and for days on end, I raged.

Family isolation as a result of interracial marriage is far from novel, but still, I was struck by my new feeling of being unmoored. While told and reassured that Roha and I are loved, we stand on the outside of what my family considered to be acceptable as deficit falsehoods about "Black people from Africa" were routinely mixed in with everyday comments and discussions. Luke (1994) suggests that White women involved in interracial relationships are viewed as 'less White.' For my family, Roha and I challenged normalized discourses of White mothering. Discourses of White motherhood are normalized in spaces. In my rural farming community they gained power and reinforce issues of hate, racism, and oppression. For Foucault (1982), techniques of power in everyday society serve to normalize discourses and ultimately control how we think and talk about specific ideas. Knowledge is not something internal to a person but is an assembled, externally given, and structured set of "claims," or as Foucault would have it, "statements" (Graham 2011). A moment like this was just one of many times in which our B $+\mathrm{W}$ was called into question. Within this rural context, the Whiteness and discourses of White supremacy were given power, power which excluded us and shaped us as liminal. Power, as I would come to learn, was specific to each context, producing and reproducing what is accepted, normalized, and therefore taken for granted.

\section{Whiteness on the A train}

It was a freezing winter morning, and I did not want to leave the comfort of our apartment, but Roha's pediatrician wanted to see him early. I was weary and worried after being awake all night, my eyes glued to Roha's chest, the chest that struggled to rise against yet another bout of pneumonia. After bundling Roha, we started the three-minute walk to the subway station. Swiping my metro card, I made my way onto the platform. After the train doors opened, I spied a seat in front of the subway map. For us, it was a good spot as Roha loved anything related to trains. Lifting his head, he pointed to the map and hoarsely whispered "train." Next to us, I noticed an older African-American woman, her hair wrapped in a crimson scarf. I closed my eyes lulled by the rhythm of the train until I felt Roha move. I opened my eyes to see the woman playing with Roha. She smiled, "Peek a boo! I see you! Peek a boo! Where are you" I smiled, and settled back into the lull, grateful for the brief rest. As the woman rose to get off at the next exit, I smiled to thank her. Her gaze did not return to me, but to Roha's dark coffee brown eyes. "You make sure your Momma doesn't make you White, OK?" A chill went down my back. I left the train shaken and confused.

While I can only interpret the meaning of this woman's making Roha "White" comment, it does, for me, represent the racialized discourses surrounding our B + W. My subjectivity in this space was one of Whiteness in our $B+W$, a Whiteness that was understood to threaten the existence of my son's Black spirit. Did she read my Whiteness and likely my mothering to Roha within our B + W as insufficient? Perhaps, she surmised, I would teach him what I, (as a White woman) thought he should know, but which is inadequate given the pervasive and ongoing assault on Black boys. Indeed, White parents often struggle to teach children their ethnic heritage in a way that challenges oppression (Twine 2001). Lazarre (1996) describes how her mothering practices to her two Black sons raised concern from her husband's family. As a Black family from the deep southern part of the U.S., they knew racial violence and were terrified she, as a White woman, would fail to prepare them for the world they would face. For this woman who showed such care and kindness to my Roha in those few train stops, I can only imagine she shared a similar concern. 
For my family, discourses of White + White motherhood were normalized, and power was reinforced in the interchanges that sought to position our B $+\mathrm{W}$ as other. For this woman, Black + Black was normalized, understood to provide a predictable outcome of protection. It also served to exclude me as a proper mother. Certainly, subjectivities of motherhood are fluid and filled with possibility and agency, but the constructions are also sites in which power is operationalized against mothers. Foucault (1980) notes that power is not one's domination over the other or of a group or a class over others; instead, power must be analyzed as something which circulates, which only functions in the form of a chain. It is never in anybody's hands (Gore 2003).

In many of these small moments, I felt judged, marginalized, and liminal. Motherhood, as I would come to understand, was a construction in each context. I became a discoverable construct. Foucault notes that subjectivities are categorizes in society, often by institutions so that we can appear normal or excluded. As he writes, "the perpetual penality that traverses all points and supervises every instant in the disciplinary institutions [that] compares, differentiates, hierarchizes, homogenizes, excludes" (1977, p. 183). Exclusion defines boundaries marking "the negative side of normalization" (Gore 1998, p. 238). Crucially, this ranking and ordering of subjectivities is not universal but depends on how words and discourses are given the power to appear as unquestioned truths. Subjectivities falling outside of these categorizations are often excluded (Gore 1998). So many times I felt excluded, deficient, and unsure. Perhaps I still do.

\section{Constituting Alternate B + W Subjectivities}

Discourses can and do gain power when they are put to use by human actors. Foucault understands this as a process of subjection, where subjection to disciplinary norms that work to constitute the subject (Foucault 1987). However, as Foucauldian theorists caution, it would be a mistake to understand discourses as determining subjectivity (Caldwell 2007). Indeed, his decentering of the subject how human beings have been made subjects, but also how discourses of power/knowledge might open new agentive possibilities for change (Caldwell 2007).

Inherent in Foucault's concept is a recognition that the subject has some capacity for self-constitution (Foucault 1987).

As B $+\mathrm{W}$, I became more aware of my own racial identity and began further unpacking my Whiteness (O'Donoghue 2004). In interchanges with my family, I was spoken to as Kara, but I am also emaye, who often reads the world through my Black son's eyes. Like other White mothers raising Black children, race had become center ( $\mathrm{O}^{\prime}$ Donoghue 2004). Thus, I also have found myself picking up discourses that have been provided by Black mothers for centuries, in an attempt to ameliorate "the American experience (that) tears away at the Black body" (McClain 2019, p. 13). My mothering and subjectivity have become one of fiercely protective B + W Emaye. Patricia Hill Collins (1995) describes what Black mothers have been doing for four hundred years as "other mothering." As she and other Black feminist authors note, Black mothers know about the marginalization of their children and take responsibility for raising Black children in a society that devalues their bodies, their spirits, and their essence (Collins 2016). I sought to learn from this, to develop ways to socialize Roha to cope with the systemic racism he would face (Verbian 2006). Like other mothers of biracial children, I wanted to create an environment that would "foster a sense of self-worth and prepare their racial injustice" (Schalge and Rudolph 2007, p. 15). Kouritzin (2016) asserts B + W mothers often serve as brokers between different ideologies of race.

In response to pervasive racism, many African American mothers have developed and sustained racial socialization approaches and strategies to help children make sense of race "in ways that are continuous, progressive, and ongoing-not merely reactive or provided in isolated responses to children's inquiries about race-related events or ideas (Hughes et al. 2006)". Through this practice, mothers aim to promote the psychological and physical health of Black children through child-rearing in a society in an attempt to combat discrimination and racism and the resulting detrimental outcomes (Coard and Sellers 2005; Blanchard et al. 2019). Parents' socialization regarding ethnicity and race 
is likely to be among the most important of these processes to prepare children to live in a racially stratified society. Yet as a White woman navigating this uncharted process, I felt isolated. Twine (2010) notes that when White women have children who are biracial, they take up identity work as part of mothering without family members and Kin with shared experiences. They often do so alone.

I was completely alone in raising Roha as his father, my husband, was away in Tanzania for work during much of his infancy and toddlerhood. Looking back on this time I, as Roots (2001) suggests, was certainly the one most affected by my biracial child's identity. I took the lead on all aspects of childcare, which included baths and mealtime and trips to the park. It also meant infusing racial, ethnic, and cultural lessons into our everyday experiences. My aim, much like the White mothers raising biracial children in Twine (2010) study, was to equip my Roha with the tools I felt he would need to exist in a White supremacist society. Yet even if my husband was located in New York, he would not have engaged in this practice. As an Ethiopian and a non-early childhood educator, he had little understanding of why racial, ethnic, and cultural socialization would benefit Roha. He believed that as a baby born in New York with a White, American mother, Roha would be raised as an American and thus would be fine. I was less sure.

I knew he needed to see himself in a strong, positive light. I looked to the wisdom Black women have long provided. I sought out books that had African-American boys as the protagonist; this quest proved very difficult as less than $10 \%$ of all books feature such protagonists. After much search, I found a subscription box of books for young African-American boys-we devoured them each month. Our conversations often began with these books. One night, tucked into his bed, I felt Roha's hand on my arm. "See momma, I have brown skin, and you have light brown skin. Baba has dark brown skin, I have brown skin, and my momma has light brown skin." His words were careful and deliberate. While spoken aloud, his words seemed not for me but for himself and his process of trying to make sense of our differences. I decided to just listen. On some occasions our conversations became quite serious and delved into historical and contemporary issues of racism and discrimination. Haunted by the rise in racial violence on television and more visible accounts of the nationalist propaganda, my goal was to prepare Roha. I needed him to be able to challenge issues of injustice, but also to face the inevitable racism that African American boys are forced to confront every day.

I was unprepared for quite how heart wrenching this would be. One day Roha and I sat on the couch, reading a book about Nelson Mandela, South Africa, apartheid, and injustice. Halfway through the book, he reached out and with his fingers began to trace an illustration depicting segregated beaches. Roha turned, a puzzled look on his face. "Emaye, could we go to the beach together"? I sighed, "No, Roha, we could not." Tears streamed down his face, and I held his shaking body close. A few minutes later he insisted "I want to go to the beach with you". Excruciating pain tore into my stomach as I confronted our reality- some people will never be able to accept the contrast of our B+W. Gathering all of my courage, I explained to Roha that some people are afraid of people that are not like themselves, and skin color is one of those differences. I explained that although this story took place in Africa, where his baba (father) is from, there are also people in the U.S. that have similar beliefs. Wiping the last tear that ran down his cheek, Roha proclaimed he would not go to any beach that said that we could not swim together.

I, like many parents of color used these painful conversations to promote ideologies and values (racial equality, freedom), long-term goals (physically and emotionally healthy and resilient adults), and short-term goals (child's developing understanding of the significance of being Black in the U.S.) (Suizzo et al. 2008). To be Roha's emaye, I would err on the side of preparation, crushing my own heart as my little boy cried. I began to understand the strength of African-American mothers who engage in this work, who know and live fear intimately and "how to live despite it and how to metabolize it for our children, so they're not consumed by it" (McClain 2019, p. 5). B + W means having conversations about my family's current reality in the U.S. I would make him aware of his, my, and our B + W subjectivities, subjectivities that would always shift, often defined by those around us. 


\section{Rectifying Liminal, Temporary, and Conflicting Constitution(s) of Raced Motherhood}

What might the process of revisiting these distressing, sometimes excruciating memories do for me, for Roha and for our B $+\mathrm{W}$ ? Furthermore, what might a poststructural rendering of these moments, with an emphasis on power, language, conflict, and instability do for the growing numbers of mothers raising children in multiracial families? For poststructuralists, individuals do not preexist, they and their social and geographical worlds are made possible only in relation to each other. So how might this aid in understanding my/our identity, and how might it matter in how we move through the world?

Plainly, this paper contributes nuanced, quotidian understandings of how certain subjectivities can be formed, and how they come to matter, complicating and contributing new ways of thinking about motherhood. We present but one way and one interpretation of how one interracial motherhood became; how it was produced, understood, regulated, and in some cases, marginalized. And it is partial at best. Admittedly, the truths of autoethnographic writing, like all writing itself, are liminal, dynamic, and contingent. Indeed, there are countless other ways this text could be read (Henward and MacGillivray 2013, 2014; Kurban and Tobin 2009). Certainly, this analysis presents possibilities but also challenges in sitting with the partial, incomplete, and temporary. In embracing the instability through interpretive and speculative approaches, we are forced to confront the shifting multitude of motherhoods, which are always raced, classed, and gendered. But, rather than a hindrance, embracing this onto-epistemological shift produces understandings that complicate and challenge many binary understandings of how mothers are known in research and more generally in life.

This deconstructive, autoethnographic approach to motherhood necessitates a displacement and process of disassembling the self (Rabinow 1997). In recognizing that I/we, are a social cultural production, dialogically co-constructed based on available discourses (and mapping and revisiting these discursive constructions), we are able show how subjectivities are constituted, regulated, and mediated through macro- and micro-moments of power, time, space. For Roha and Kara, this permits understandings of how mothers are constituted, made again over and over, depending on their social world. As these few brief reflections show, B + W subjectivit(ies) shifted as they were produced by socially discursive practices formed in moments, (Henward and MacGillivray 2014; Foucault 1972).

By engaging in a constant practice of reflexive attention to the past, present, and future moments of subjectification within complex and contradictory discursive arenas, our analysis demonstrates that raced motherhoods are constituted in multiple ways, always. While the tracing of these discourses suggests that subjectivities of mothering are highly regulated, normalized, and categorized (Foucault 1977), they also show how subjectivities are far from stable. Foucauldian theory allows us to understand these actions as always produced by, and thus one and the same with the political. While carried out by individuals, they are representative of broader discourses around motherhood and race. Foucault understands networks of power as far from contained, existing in the interchanges between individuals. Hence, B + W subjectivity is not produced between mother and child, but constructed by various discourses and their interactions and reception in our many social, cultural, and political contexts. We also demonstrate how $\mathrm{B}+\mathrm{W}$ is far from fixed; we are seen as too White in certain contexts and too Black in certain contexts. We are always in relation to surroundings; how our $B+W$ is constituted is informed by larger social texts of motherhood and race. Indeed, mothers are always "imbued with tremendous social, cultural, political, economic, psychological and personal significance" (DiQuinzio 1999, p. viii).

The deconstructive playfulness of poststructural theory that we employ in this analysis should not obscure the very real force that structural violence can and does inflict on humans. Indeed, Kara experienced many of these moments as racist, essentializing, and in some cases, so agonizing that they still bring tears and fresh pain. Yet there is for us a small amount of possibility for Kara and perhaps for other mothers which might be generated. By providing space for considering "otherwise" this analysis affords alternate narratives for those ensnared in regimes of truth (which, of course is all of us). For Foucault, this is a political act. As we deconstruct problematic and normative narratives, we simultaneously engage in an ethic of care. Foucault (1987) reminds us, "one cannot care for self 
without knowledge"; he explains "To care for self is to fit one's self out with these truths. That is where ethics is linked to the game of truth" (p. 116). This we argue will only grow in importance as every day more multiracial families are created, and more liminal motherhoods are constituted. While each who mothers in a multiracial family will undoubtedly have their own experiences, joys, and challenges, this autoethnography highlights possibility and potential in its attention to overlooked voices and experiences, experiences that have long been unaccounted for and too often silenced within scholarship of mothering.

Author Contributions: K.R.M. was responsible for data collection, conceptualization, and literature review. A.S.H. was responsible for literature review, research methods, and data analysis and discussion. All authors have read and agreed to the published version of the manuscript.

Funding: This research received no external funding.

Conflicts of Interest: The authors declare no conflict of interest.

\section{References}

Arribas-Ayllon, Michael, and Valarie Walkerdine. 2008. Foucauldian discourse analysis. In The Sage Handbook of Qualitative Research in Psychology. Edited by Willig C and Stainton Rogers W. Southend Oaks: SAGE Publications, pp. 91-108.

Blanchard, Sheresa Boone, Stephanie Irby Coard, Belinda J. Hardin, and Mariana Mereoiu. 2019. Use of Parental Racial Socialization with African American Toddler Boys. Journal of Child and Family Studies 28: 387-400. [CrossRef]

Caballero, Chamion. 2005. Mixed Race Projects: Perceptions, Constructions, and Implications of Mixed Race in the U.K. and U.S.A. Ph.D. dissertation, University of Bristol, Bristol, UK.

Caldwell, Raymond. 2007. Agency and change: Re-evaluating Foucault's legacy. Organization 14: 769-91. [CrossRef]

Coard, Stephanie, and Robert Sellers. 2005. African American families as a context for racial socialization. In African American Family Life: Ecological and Cultural Diversity. New York: The Guilford Press, pp. 264-84.

Collins, Patricia Hill. 1995. Bloodmothers, othermothers, and women-centered networks. In Reconstructing Gender: A Multicultural Anthology. California: Mayfield Pub Co, pp. 317-23.

Collins, Patricia Hill. 2016. Shifting the center: Race, class, and feminist theorizing about motherhood. In Mothering. London: Routledge, pp. 45-65.

DiQuinzio, Patrice. 1999. The Impossibility of Motherhood: Feminism, Individualism, and the Problem of Mothering. New York: Routledge.

Donnella, Leah. 2016. All mixed up: What do we call people of multiple backgrounds. Code Switch: Word Watch @ NPR. Available online: https://www.npr.org/sections/codeswitch/2016/08/25/455470334/all-mixed-up-whatdo-we-call-people-of-multiple-backgrounds (accessed on 9 October 2019).

Dumas, Michael. 2016. My brother as "Problem" neoliberal governmentality and interventions for black young men and boys. Educational Policy 30: 94-113. [CrossRef]

Ellis, Carolyn, and Arthur P. Bochner. 2000. Autoethnography, personal narrative, reflexivity. In Handbook of Qualitative Research, 2nd ed. Lincoln: Denzin, Thousand Oaks: Sage, pp. 733-68.

Ellis, Carolyn, Tony E. Adams, and Arthur P. Bochner. 2011. Autoethnography: An overview. Historical Social Research 36: 273-90.

Ellis, Carolyn. 1999. Heartful autoethnography. Qualitative Health Research 9: 669-83. [CrossRef]

Foucault, Michel. 1972. The Archaeology of Knowledge. Translated by S Smith. New York: Routledge.

Foucault, Michel. 1977. Discipline and Punish. Translated by Alan Sheridan. New York: Vintage.

Foucault, Michel. 1980. "Prison talk", interview by J. Brochier. In Power/Knowledge: Selected Interview and Other Writings 1972-1977. Edited by C. Gordon. New York: Pantheon Books, pp. 37-54.

Foucault, Michel. 1982. The subject and power. Critical Inquiry 8: 777-95. [CrossRef]

Foucault, Michel. 1987. The Ethic of Care for the Self as a Practice of Freedom: An Interview with Michel Foucault on 20 January 1984 in The Final Foucault: Studies on Michel Foucault's Last Works. Philosophy $\mathcal{E}$ Social Criticism 12: 112-31.

Gannon, Suzanne. 2006. The (im)possibilities of writing the self-writing: French poststructural theory and autoethnography. Cultural Studies? Critical Methodologies 6: 474-95. [CrossRef] 
Gatson, Sarah. 2003. On being amorphous: Autoethnography, genealogy, and a multiracial identity. Qualitative Inquiry 9: 20-48. [CrossRef]

Goodall, Harold Jr. 2008. Writing Qualitative Inquiry: Self, Stories, and Academic Life. Walnut Creek: Left Coast Press.

Gore, Jennifer. 1995. Foucault's poststructuralism and observational education research: A study of power relations. In After Postmodernism: Education, Politics and Identity. Edited by R. A. Smith and P. Wexler. London: Psychology Press, pp. 98-111.

Gore, Jennifer. 1998. Disciplining Bodies: on the continuity of power relations in pedagogy. In Foucault's Challenge: Discourse, Knowledge and Power in Education. Edited by T. S. Popkewitz and M. Brennan. New York: Teachers College Press, pp. 231-51.

Gore, Jennifer. 2003. What we can do for you! What can "we" do for "you"? Struggling over empowerment in critical and feminist pedagogy. In The Critical Pedagogy Reader. London: Routledge, pp. 331-48.

Grace, Donna J., and Allison Sterling Henward. 2013. Investigating young children's talk about the media. Contemporary Issues in Early Childhood 14: 138-54. [CrossRef]

Graham, Linda. 2011. The product of text and "other" statements: Discourse analysis and the critical use of Foucault. Educational Philosophy and Theory 43: 663-74. [CrossRef]

Henward, Allison Sterling, and Laurie MacGillivray. 2013. "It's a combination of the Bible and what's in your heart": Unresolvable tensions and contested narratives in a southern child care center. Journal of Curriculum Theorizing 28: 98-108.

Henward, Allison Sterling, and Laurie MacGillivray. 2014. Bricoleurs in preschool: Girls poaching horror media and gendered discourses. Gender and Education 26: 726-42. [CrossRef]

Henward, Allison Sterling. 2018. Examining discursive formations in early childhood media research: A genealogical analysis. Global Studies of Childhood 8: 225-37. [CrossRef]

Hughes, Diane, James Rodriguez, Emilie P. Smith, Deborah J. Johnson, Howard C. Stevenson, and Paul Spicer. 2006. Parents' ethnic-racial socialization practices: A review of research and directions for future study. Developmental Psychology 42: 747. [CrossRef]

Jones, Nick, and Jungmiwha J. Bullock. 2013. Understanding who reported multiple races in the U.S. U.S. decennial Census: Results from Census 2000 and the 2010 Census. Family Relations 62: 5-16. [CrossRef]

Kouritzin, Sandra. 2016. Mothering across colour lines: Decisions and dilemmas of White birth mothers of mixed-race children. Journal of Multilingual and Multicultural Development 37: 735-47. [CrossRef]

Kurban, Fikriye, and Joseph Tobin. 2009. 'They Don't Like Us': Reflections of Turkish Children in a German Preschool. Contemporary Issues Early Childhood 10: 24-34. [CrossRef]

Lazarre, Jane. 1996. Beyond the Whiteness of Whiteness: Memoir of a White mother of Black Sons. Durham: Duke University Press.

Love, Bettina. 2014. "I see Trayvon Martin": What teachers can learn from the tragic death of a young black male. The Urban Review 46: 292-306. [CrossRef]

Love, Bettina. 2016. Anti-Black state violence, classroom edition: The spirit murdering of Black children. Journal of Curriculum and Pedagogy 13: 22-25. [CrossRef]

Luke, Carmen. 1994. White women in interracial families: Reflections on hybridization, feminism, identities and racialized othering. Feminist Issues 14: 49-72. [CrossRef]

Mama, Amita. 2002. Beyond the Masks: Race, Gender and Subjectivity. New York: Routledge.

McClain, Dani. 2019. We Live for the We: The Political Power of Black Motherhood. New York: Bold Type Books.

Miller, Tina. 2005. Making Sense of Motherhood: A Narrative Approach. Cambridge: University Press Cambridge.

Murad, Nora Lester. 2005. The politics of mothering in a "mixed" family: An autoethnographic exploration. Identities: Global Studies in Power 12: 479-503. [CrossRef]

O'Donoghue, Margaret. 2004. Racial and ethnic identity development in White mothers of biracial, Black-White children. Affilia 19: 68-84. [CrossRef]

Pollock, Mica. 2009. Colormute: Race Talk Dilemmas in an American School. Princeton: Princeton University Press.

Rabinow, Paul, ed. 1997. Ethics: Subjectivity and truth: Essential works of Foucault 1954-1984. New York: The New Press, volume 1.

Rauktis, Mary Elizabeth, Fusco Rachel A., Goodkind Sara, and Bradley-King Cynthia. 2016. Motherhood in liminal spaces: White mothers' parenting Black/White children. Journal of Women and Social Work 31: 434-49. [CrossRef] 
Rollock, Nicola. 2012. The invisibility of race: Intersectional reflections on the liminal space of alterity. Race, Ethnicity and Education 15: 65-84. [CrossRef]

Roots, Maria P. P. 2001. Love's Revolution: Interracial Marriage. Philadelphia: Temple University Press.

Schalge, Susan, and Cynthia Rudolph. 2007. Race a cultural construction, race as social reality. Journal of the Association for Research on Mothering 9: 9-19.

Scott, Kimberly, and Allison Sterling Henward, eds. 2016. Women Education Scholars and Their Children's Schooling. New York: Routledge.

Seiter, Ellen. 1990. Different Children, Different Dreams: Racial Representation in Advertising 1. Journal of Communication Inquiry 14: 31-47. [CrossRef]

Suizzo, Marie-Anne, Courtney Robinson, and Erin Pahlke. 2008. African American mothers' socialization beliefs and goals with young children: Themes of history, education, and collective independence. Journal of Family Issues 29: 287-316. [CrossRef]

Thompson, Becky, and Sangeeta Tyagi. 1996. Introduction, storytelling as social conscience: The power of autobiography. In Names We Call Home: Autobiography on Racial Identity. Edited by B. Thompson and S. Tyagi. London: Routledge, pp. ix-xvii.

Twine, France Winddance. 2001. Transgressive women and Transracial mothers: White women and critical race theory. Meridians: Feminism, Race, Transnationalism 1: 130-53. [CrossRef]

Twine, France Winddance. 2010. The White Side of Black Britain: Interracial Intimacy and Racial Literacy. Raleigh: Duke University Press.

Verbian, Channa. 2006. White birth mothers of Black/White biracial children: Addressing the racialized discourses in feminist and multicultural literature. Journal of the Association for Research on Mothering 8: 213-22.

Walkerdine, Valarie. 2003. Reclassifying upward mobility: Femininity and the neo-liberal subject. Gender and Education 15: 237-48. [CrossRef]

Zembylas, Micaelinos. 2003. Interrogating "teacher identity": Emotion, resistance, and self-formation. Educational Theory 53: 107-27. [CrossRef]

(C) 2020 by the authors. Licensee MDPI, Basel, Switzerland. This article is an open access article distributed under the terms and conditions of the Creative Commons Attribution (CC BY) license (http://creativecommons.org/licenses/by/4.0/). 